\title{
Common Bean: Experimental Indicator Plant for Citrus leprosis virus $C$ and Some Other Cytoplasmic-Type Brevipalpus-Transmitted Viruses
}

L. C. Garita, A. D. Tassi, R. F. Calegario, and E. W. Kitajima, Departamento de Fitopatologia e Nematologia, Escola Superior de Agricultura Luiz de Queiroz, Universidade de São Paulo, Caixa Postal 9, 13418-900 Piracicaba, SP, Brazil; S. A. M. Carbonell, Centro de Grãos e Fibras, Instituto Agronômico de Campinas, Caixa Postal 28, 12020-902, Campinas, SP, Brazil; and J. Freitas-Astúa, Embrapa Mandioca e Fruticultura, Caixa Postal 7, 44380-000 Cruz das Almas, BA, Brazil, and Centro APTA Citros Sylvio Moreira, Instituto Agronômico de Campinas, Caixa Postal 4, 13490-970 Cordeirópolis, SP, Brazil

\begin{abstract}
Garita, L. C., Tassi, A. D., Calegario, R. F., Kitajima, E. W., Carbonell, S. A. M., and Freitas-Astúa, J. 2013. Common bean: Experimental indicator plant for Citrus leprosis virus $C$ and some other cytoplasmic-type Brevipalpus-transmitted viruses. Plant Dis. 97:1346-1351.

Citrus leprosis (CL) caused by Citrus leprosis virus $C$ (CiLV-C) is present in Latin America from Mexico to Argentina, where citrus plants are grown. CiLV-C is transmitted by the tenuipalpid mite, Brevipalpus phoenicis, causing localized lesions on citrus leaves, fruit, and stems. One limitation to study of the virus-vector-host relationship in this pathosystem is the lack of a suitable assay plant. On Citrus spp. used as susceptible hosts, symptoms may take weeks or months to appear after experimental inoculation by viruliferous mites. Common bean (Phaseolus vulgaris) was found to respond with localized necrotic lesions after inoculation with viruliferous B. phoenicis in 5 days. Thus far, 113 tested common bean varieties and lines and some recent accessions of varied genetic background behaved in a similar way. Black bean 'IAC Una' was adopted as a standard test variety. When

inoculated leaves were left at 28 to $30^{\circ} \mathrm{C}$, the period for the lesion appearance was reduced to only 2 days. Confirmation that the lesions on common bean leaves are caused by CiLV-C were made by transmission electron microscopy, immunofluorescence, enzyme-linked immunosorbent assay, and reverse-transcription polymerase chain reaction specific for CiLV-C. Common bean plants mite-inoculated with some other cytoplasmic-type Brevipalpus-transmitted viruses (BrTVs) (Passion fruit green spot virus, Solanum violaefolium ringspot virus, Ligustrum ringspot virus, and Hibiscus green spot virus) also responded with necrotic local lesions and may serve as test plants for these viruses. Two nuclear types of BrTV (Coffee ringspot virus and Clerodendrum chlorotic spot virus) were unable to produce symptoms on common bean.
\end{abstract}

Citrus leprosis virus $C$ (CiLV-C) is the causal agent of citrus leprosis (CL), a destructive disease of citrus crop transmitted by the tenuipalpid mite Brevipalpus spp. and characterized by inducing localized lesions on the leaves, fruit, and stems of infected plants $(2,37)$. The entire genome of this virus was sequenced $(31,36)$. Because of its distinct genomic organization, a new genus, Cilevirus, was proposed and accepted by the International Committee on Taxonomy of Viruses $(30,31)$. CL was known in Florida since 1860 but the first official description of the disease was made in the early 1900s (10). Leprosis disappeared from Florida after the 1960 s, possibly due to a series of freezes and the use of sulfur, which gradually decreased the source of inoculum (8). There is now evidence that CL in Florida may have been caused by the nuclear type of the CiLV (CiLV-N; 18). CiLV-C is confirmed to have been present from Argentina to Mexico since its discovery in the 1920s in Paraguay, Argentina, and Brazil (2). The role of Brevipalpus mites as vector of CiLV-C was first established in 1940 by Frezzi (12) in Argentina. In these works, the mite vector was identified as Tenuipalpus pseudocuneata Blanchard, a junior synonym for B. obovatus Donnadieu. B. phoenicis Geijskes was determined as a CiLV-C vector in Brazil (33) and has been the most commonly identified species transmitting the virus (2).

Citrus spp. have long been considered to be the sole hosts for CiLV-C but mechanical transmission experiments showed that the virus could be transmitted to other species in which it also caused localized lesions (9). More recently, it has been demonstrated that CiLV-C can be mite transmitted to a quite wide range of experi-

Corresponding author: E. W. Kitajima, E-mail: ewkitaji@usp.br

Accepted for publication 28 April 2013.

http://dx.doi.org/10.1094/PDIS-12-12-1143-RE

(C) 2013 The American Phytopathological Society mental plant species $(13,35)$. It also was found naturally infecting a non-Citrus rutaceae, Swinglea glutinosa Merr., commonly used as a hedgerow in Colombia (28), and Commelina benghalensis L., a weed present in citrus orchards in Brazil (34). These data clearly show that the epidemiology of CL may be more complex than initially thought.

Several studies trying to obtain detailed information of the CL pathosystem have been hindered by the lack of a suitable assay plant. Citrus spp. vary in their susceptibility for CiLV-C, ranging for the highly sensitive sweet orange (Citrus sinensis (L.) Osbeck) to moderately susceptible mandarin ( $C$. reticulata Blanco) and grapefruit $(C$. paradisi McFarl.) and practically immune lemon $(C$. limon L.) (2). However, even the susceptible sweet orange may take approximately 4 weeks to show the initial chlorotic lesions after experimental mite inoculation $(2,7)$.

This article reports the use of common bean (Phaseolus vulgaris L.) as a suitable indicator plant for CiLV-C because infection with viruliferous $B$. phoenicis results in localized necrotic lesions in five or less days. Such a system will contribute to better understanding of the CiLV-C-Brevipalpus relationship.

\section{Materials and Methods}

Colonies of B. phoenicis. Nonviruliferous mites were obtained from colonies of $B$. phoenicis maintained by Celso Omoto (Departamento de Entomologia, Escola Superior de Agricultura Luiz de Queiroz), Maria Andréia Nunes (Centro APTA Citros Sylvio Moreira), and Daniel Junior de Andrade (Departamento de Fitossanidade, FCAVJ/UNESP). To keep a stock of nonviruliferous colonies, B. phoenicis mites obtained from these sources were reared on uninfected sweet orange fruit collected from unsprayed orchards. About two-thirds of the fruit was covered by a thin layer of paraffin after dipping it in melted paraffin. An arena 4 to $5 \mathrm{~cm}$ in diameter in the region of the fruit not covered by paraffin was delimited with entomological glue Tanglefoot, where mites were confined. 
Virus source. Lesions on sweet orange leaves or fruit caused by CiLV-C were used as a source of inoculum. These samples came from unsprayed experimental fields where leprosis was endemic (Colina and Matão municipalities, state of São Paulo, Brazil). Detached leaves with leprotic lesions were kept on moist filter paper in a petri dish and mites were transferred from stock colonies on them. In the case of symptomatic fruit, they were prepared in the same way as the stock, except that the arena was formed by the surface with lesions. About 50 mites were placed on CiLV-C-infected sweet orange leaves or fruit and left at least 4 to 5 days to be sure that most of them had acquired the virus. Preliminary data indicated that the minimum virus acquisition feeding period was approximately $4 \mathrm{~h}$ (A. D. Tassi, personal communication).

Common bean plants. In all, 113 varieties and lines and some recent accessions of common bean (Table 1), mostly from the Germplasm Collection Bank of the Centro de Grãos e Fibras of the Instituto Agronômico de Campinas (IAC), were tested. Two additional experimental lines of transgenic bean resistant to Bean golden mosaic virus (BGMV; 4) were also included. Seeds were planted in small plastic pots (approximately $10 \mathrm{~cm}$ in diameter and $8 \mathrm{~cm}$ high) filled with sterilized soil and kept in a greenhouse. Three plants of each common bean type were tested for the susceptibility to CiLV-C about 1 week after germination, when the two initial leaves were completely expanded.

Mite inoculation. Five adult mites that fed on leaf or fruit leprotic local lesions for at least 3 days were transferred onto each of the two leaves with the help of a fine metal needle. Entomological glue was applied onto the petiole to avoid mite migration from the leaf. One plant received five mites from the stock, nonviruliferous colony and was left as control. Visual readings of the symptoms were made daily for a period of 10 days. A variant of this procedure was to detach the leaves from the plant and keep them on moist filter paper in a petri dish (Fig. 1A).

High-temperature treatment. To evaluate the possible effect of the temperature on the appearance of the lesions induced by CiLV$\mathrm{C}$ on primary leaves, either leaves from potted plants or detached leaves infested with viruliferous mites were placed in a temperature-controlled germination chamber (Tecnal, model TE 402) at $28^{\circ} \mathrm{C}$. For these experiments, the common bean 'IAC Una', with black grains, was selected. As in the above-described experiments, five mites that fed on fruit or leaf lesions were placed on each leaf. Readings of the symptoms were made daily after initial mite inoculation.

Detection of CiLV-C in symptomatic common bean plants. To demonstrate that the lesions caused on the leaves of these different common bean types were caused by CiLV-C, leaf lesions from eight distinct bean types ('BRS Cometa', 'SCS 202 Guará',
'ESAL-767', 'IAC Ybaté', 'BRS Esplendor', 'G-3353', 'Mexico 324', and 'Baetão 83') in addition to IAC Una were submitted to morphological, immune, and molecular assays to detect the virus in the tissues, soon after the appearance of the lesions. Samples from uninfected plants were included in these assays as negative controls.

Reverse-transcription polymerase chain reaction. Attempts to detect CiLV-C in the lesions caused by viruliferous mites on leaves of common bean plants were also made by reverse-transcription polymerase chain reaction (RT-PCR, following the protocol established by Locali et al. (29) for the amplification of a 339-bp region within the movement protein gene of the virus.

Enzyme-linked immunosorbent assay. Plate-trapped antigen (PTA) enzyme-linked immunosorbent assay (ELISA) (27) was employed to detect the virus in the extracts of lesions on bean leaves using antiserum raised against the putative CiLV-C nucleocapsid protein (p29) (5) at 1:1000 dilution. For immune and molecular detection of CiLV-C in common bean leaf lesions, noninoculated bean leaves were used as negative controls and sweet orange leaf lesions caused by CiLV-C as positive controls. In ELISA, to be considered positive for CiLV-C infection, an optical density at $405 \mathrm{~nm}\left(\mathrm{OD}_{405}\right)$ reading had to be superior to three times of the reading of the extract of the uninfected, control sample.

Transmission electron microscopy. Common bean leaf fragments with the lesions were processed and embedded in the Spurr's epoxy resin to detect cytopathic effects caused by CiLV-C (37), as described by Kitajima and Nome (21).

Immunofluorescence microscopy. Fragments of the leaf lesion tissues were fixed in buffered glutaraldehyde/paraformaldehyde mixture and embedded in LRWhite resin. Semi-thin sections, approximately $1.5 \mu \mathrm{m}$ thick, were mounted on glass slides. The sections were processed for immunofluorescence as described by Kikkert et al. (16) using an antibody against p29 (putative coat protein) of CiLV-C, diluted at 1:1000. The antigenantibody complexes were detected in situ by using anti-rabbit goat antibody conjugated to fluorescein isothiocyanate and examined in a Zeiss Axioskop photomicroscope equipped with UV light illumination. In both transmission electron microscopy (TEM) and Immunofluorescence microscopy assays, noninoculated control tissues were processed in a similar manner and examined as controls.

Assays for susceptibility of bean plants to other Brevipalpustransmitted viruses. To verify whether or not common bean plants are also susceptible to infection by other cytoplasmic types of Brevipalpus-transmitted viruses (BrTV-Cs) (19), mites were collected from the following plants experimentally infested by Brevipalpus mites and infected with their respective viruses: (i)

Table 1. The 113 common bean (Phaseolus vulgaris) varieties, lines, and some recent accessions tested for their susceptibility to Citrus leprosis virus $C$

\begin{tabular}{|c|c|}
\hline Seed coat & Varieties, lines, accessions ${ }^{a}$ \\
\hline Red seed coat $(n=24)$ & $\begin{array}{l}\text { AB 136, Chiapas } 73 \text { rojo obscuro, CORE 564, Diacol calima, Don Timoteo, Dor 476, DRK 18, Frijolica, } \\
\text { G1402, G2333, G51307, IAC Boreal, IAC Harmonia, Iran Jiroft 396, MDRK, Mexico 54, Montcalm, } \\
\text { Mortiño, PI 174994, Red Kidney, Riz 30, Rojo de Guia, Roxinho Opaco, TIB } 3042\end{array}$ \\
\hline White seed coat $(n=15)$ & $\begin{array}{l}\text { 83N393, Branco Argentino, G2301, G7365, G23858, Kaboom, Lunatus, Mercana, Mexico 222, Michelite, } \\
\text { PAN 72, Ojo de Venado, Otebo GN, Perry Marrow, Widuza }\end{array}$ \\
\hline Brown and yellow seed coat $(n=26)$ & $\begin{array}{l}\text { 6N324, Amendoim, Baetão 83, Bat 332, Bat 477, CF 220240, CNFM 10243, HFS 465-63-1, Flor de Mayo, } \\
\text { G5686, G2809, G9811, G10474, G19833, G19927, IAC Bico-de-ouro, IAC Centauro, IAC Esperança, IPA } \\
\text { 1, IPA 6, Jalo Precoce, Mexico 324, Mulatinho, PI 1796, PI 20262, SEA } 2\end{array}$ \\
\hline Pink seed coat $(n=1)$ & Rosinha G2 \\
\hline Black seed coat $(n=17)$ & $\begin{array}{l}\text { A 211, BRS Esplendor, Cornell 49-242, IAC Diplomata, IAC Tunã, IAC Una, G3174, G3353, IPR Uirapuru, } \\
\text { Frijol Negro, Jamapa, Preto 129, Preto Uberabinha, RAZ 56, Rim de porco preto, TO, TU }\end{array}$ \\
\hline Cream beige seed coat $(n=30)$ & $\begin{array}{l}\text { Branquinho, BRS Cometa, BRS Estilo, BRS Pontal, Carioca comum, Carioca MG, Emp 407, ESAL-767, } \\
\text { FB/GP 258-2, G2858, Gen C2-1-6-1, IAC Alvorada, IAC Carioca Akytã, IAC Carioca Aruã, IAC Carioca } \\
\text { Eté, IAC Carioca Tybatã, IAC Carioca Taurino, IAC Formoso, IAC Ybaté, IAPAR 31, IAPAR 81, IPR } \\
\text { Eldorado, LR 9115302, Pérola, Pinto 114, Pinto 1564, Pinto nacional, SCS } 202 \text { Guará, D1*, D2* }\end{array}$ \\
\hline
\end{tabular}

a Asterisk (*) indicates transgenic lines resistant to Bean golden mosaic virus (4). 
passion fruit (Passiflora edulis Sims. f. flavicarpa Deg.) leaves infected by Passion fruit green spot virus (PFGSV) (22); (ii) Chinese privet (Ligustrum sinensis Lour.) leaves infected by Ligustrum ringspot virus (LigRSV) (23); (iii) hibiscus (Hibiscus rosa-sinensis L.) leaves infected by Hibiscus green spot virus (HGSV) (23); and (iv) Solanum violaefolium Schott. leaves infected by Solanum violaefolium ringpot virus (SvRSV) (23). Except for SvRSV, where the mite was identified as B. obovatus, in the other three cases the mite species was $B$. phoenicis. Five mites were transferred to primary leaves of three potted bean (IAC Una) plants and symptom appearance was observed at daily intervals for 2 weeks. To certify that the lesions were caused by the inoculated viruses, leaf lesion tissues were processed for TEM, as mentioned above. For PFGSV and SvRSV, for which specific primers are available $(1,11)$, the lesions were assayed to detect these viruses by RT-PCR. Two other nuclear types of BrTV (BrTV-N; 19) were included in these tests: Coffee ringspot virus (CoRSV) (6) and Clerodendrum chlorotic spot virus (ClCSV) (20), assayed as described for BrTV-C.

\section{Results}

All 113 assayed common bean lines and cultivars were susceptible to CiLV-C, responding with localized necrotic lesions 5 to 6 days after infestation by viruliferous $B$. phoenicis. Lesions were produced in the primary pair of unifoliated leaves, either still attached to the plant or detached and kept in a moist petri dish (Table 1; Fig. 1). Of all tested bean types, IAC Una, with a black seed coat, was chosen because of the easy availability of the seed and good germination rates. Trifoliate leaves also were revealed to be susceptible to CiLV-C, responding with similar necrotic lesions within 5 to 6 days after infestation by viruliferous mites. However, the unifoliated pair of leaves was commonly used, because it becomes usable in a shorter time, about 1 week after germination. Despite some slight variation in the pattern of the lesions among assayed common bean lines and varieties, it was not possible to associate these variations with their genetic background. When kept in a germination chamber at $28^{\circ} \mathrm{C}$, inoculated primary

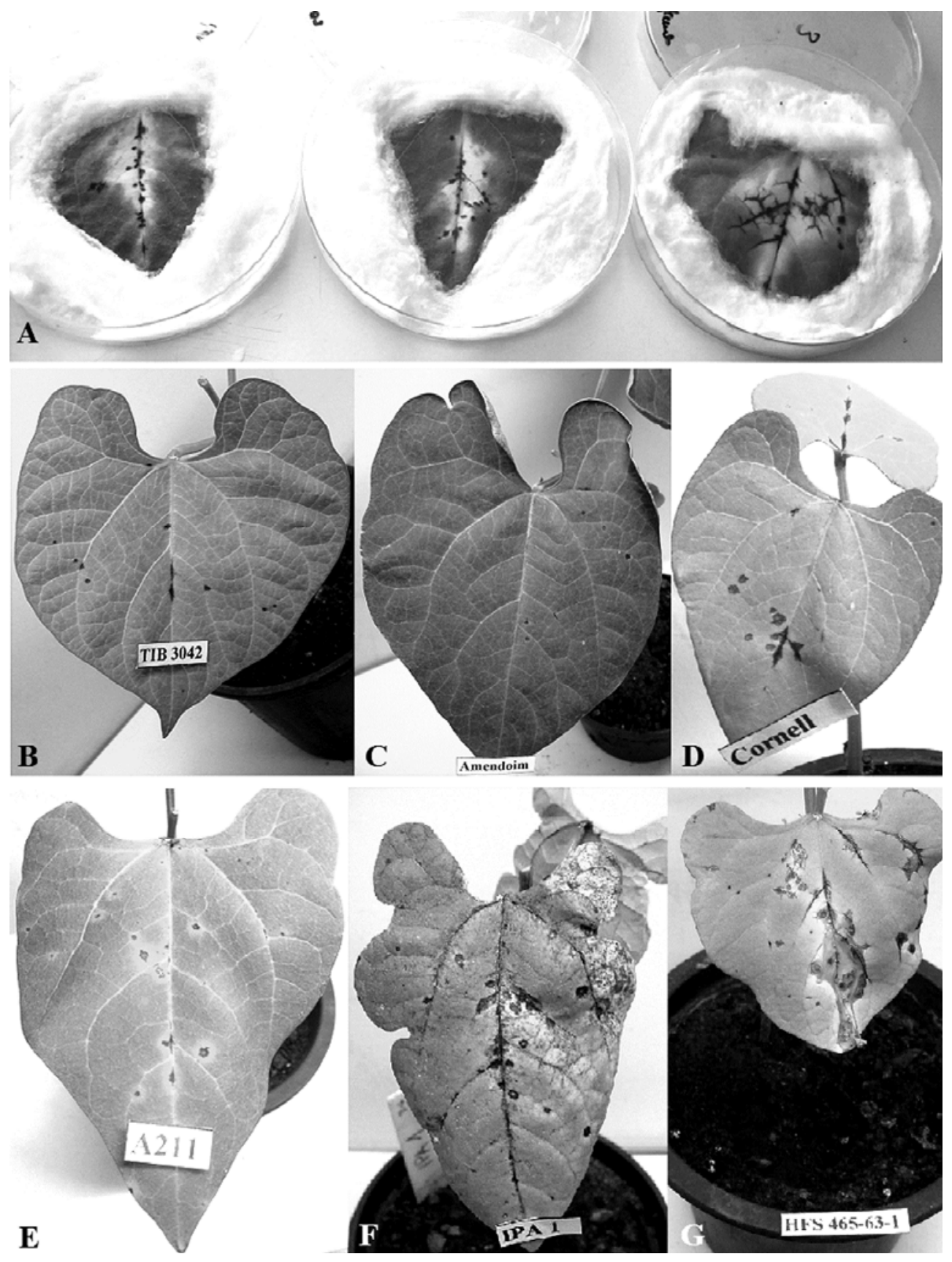

Fig. 1. Local lesions on common bean caused by Brevipalpus mite infection of Citrus leprosis virus C. A, Necrotic lesions on detached leaves of 'IAC Una'; B-G, Lesions on different varieties and lines of common bean: B, TIB 3042; C, Amendoim; D, Cornell 49-242; E, A 211; F, IPA 1; G, HFS 465-63-1. 
leaves of IAC Una produced necrotic lesions in 2 days. Bean leaves infested with nonviruliferous mites did not develop lesions.

Lesions were usually small, round, and brownish (Fig. 1A-G). Sections revealed that most cells in these lesions were necrotic and a few cells next to them still contained virions and viroplasma (Fig. 2). With time, some lesions grew in size (Fig. 1A, F, and G). The pattern of the distribution of the lesions on inoculated leaves confirms the habit of the mites to feed on or near the veins. Some of the veins became also necrotic for a short length (Fig. 1 A, D, and $\mathrm{G})$, possibly due to the necrosis of the elongated cells along the bundle sheath and the collapse of the vessels, although CiLV-C does not invade phloem tissues (19).

Confirmation that the lesions were caused by CiLV-C was demonstrated not only in bean IAC Una but also in eight randomly selected common bean genotypes by the following: (i) examination of thin sections of the lesion tissues by TEM, which revealed the presence of CiLV-C virions within cisternae of the endoplasmic reticulum and electron-dense cytoplasmic inclusions (viroplasm) (Fig. 2), as previously observed in leaf and fruit tissues of sweet orange leaves infected by CiLV-C (9,37); (ii) in situ immunofluorescence, which demonstrated the presence of CiLV-C p29 (putative nucleocapsid) protein in the tissues of the lesion (Fig. 3); (iii) RT-PCR assays on the extract of the lesions, which consistently amplified fragments of expected size in the nine common bean types assayed (Fig. 4), using specific CiLV-C primers (29); and (iv) ELISA assays on the lesion extracts with antiserum against p29 protein of the CiLV-C, in which a positive reaction was observed with most of the tested samples $\left(\mathrm{OD}_{405}\right.$ readings of extracts of the control were approximately 0.005 and those of the extracts from CiLVC-infected samples varied from 0.030 to 0.300 ). In all the experiments, tissue samples from uninfected control bean leaf results were negative and, from sweet orange leaf lesions (positive controls), were positive.

All of the BrTV-Cs tested (PFGSV, LigRSV, HGSV, and SvRSV) induced necrotic local lesions on IAC Una bean leaves after inoculation with viruliferous mites but not the tested BrTV-Ns (CoRSV and ClCSV). Lesions took a few days longer than CiLV-C to appear, usually 7 to 10 days. Demonstration that the lesions were caused by these BrTV-Cs was confirmed by the detection of characteristic bacilliform particles and the cytoplasmic viroplasm in the tissues by TEM. RT-PCR using specific primers for PFGSV and SvRSV amplified nucleotide sequences of the expected size.

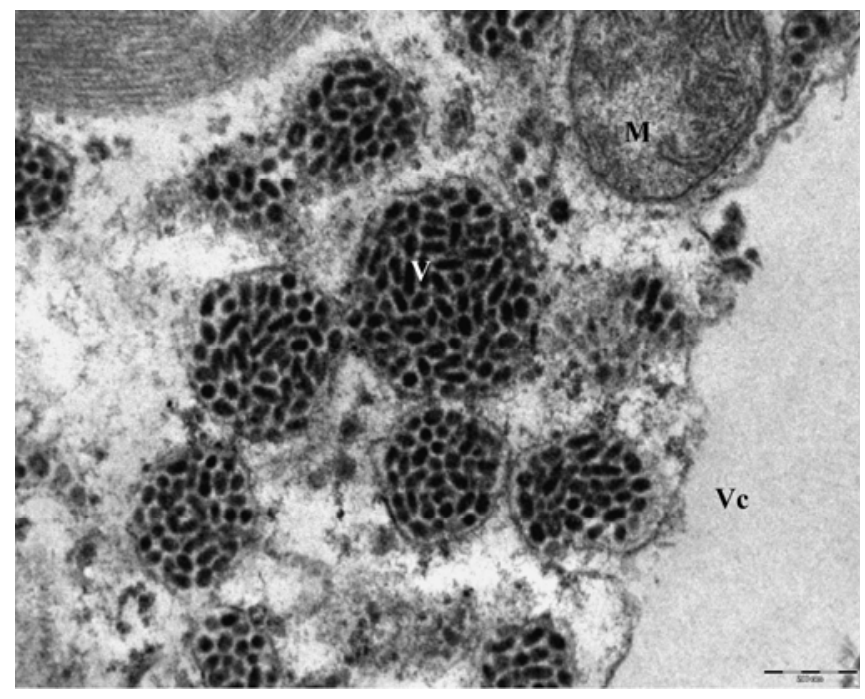

Fig. 2. Transmission electron micrograph of a thin section of a lesion on common bean 'IAC Una' caused by Brevipalpus mite inoculation of Citrus leprosis virus $C$. Viral particles $(\mathrm{V})$ are present within cisternae of the endoplasmic reticulum. $\mathrm{M}=$ mitochondrion and $\mathrm{Vc}_{\mathrm{c}}=$ vacuole

\section{Discussion}

The original discovery that bean plants are susceptible to CiLV$\mathrm{C}$ was serendipitous. During his Ph.D. work on mite symbionts at the Institute for Biodiversity and Ecosystem Dynamics of the University of Amsterdam, T. V. M. Groot maintained isoline colonies of Brevipalpus mites collected from several parts of the world on 'Mercana' common bean (14). He noticed that one particular isoline of mites collected in the state of São Paulo, Brazil, consistently caused necrotic spots on the leaves. Further assays demonstrated that the lesions were caused by CiLV-C (15). Probably the mite was collected from a CiLV-C-infected sweet orange plant and the virus was maintained throughout successive transfers.

All 113 varieties and lines of common bean tested thus far, regardless of the seed coat color and geographic origin, were revealed to be susceptible to CiLV-C. The two transgenic bean lines resistant to BGMV (4) were also susceptible, indicating that BGMV-induced resistance mediated by interference RNA (RNAi) does not affect CiLV-C infection. Further assays on other common bean lines and cultivars will be made to search for a possible immune plant which may allow genetic assays to pinpoint a gene or genes for such immunity.

At least two different types of viruses are known to be transmitted by Brevipalpus mites, based on cytopathology induced by them in the infected cells (19). (i) BrTV-C, with short-bacilliform (60 to

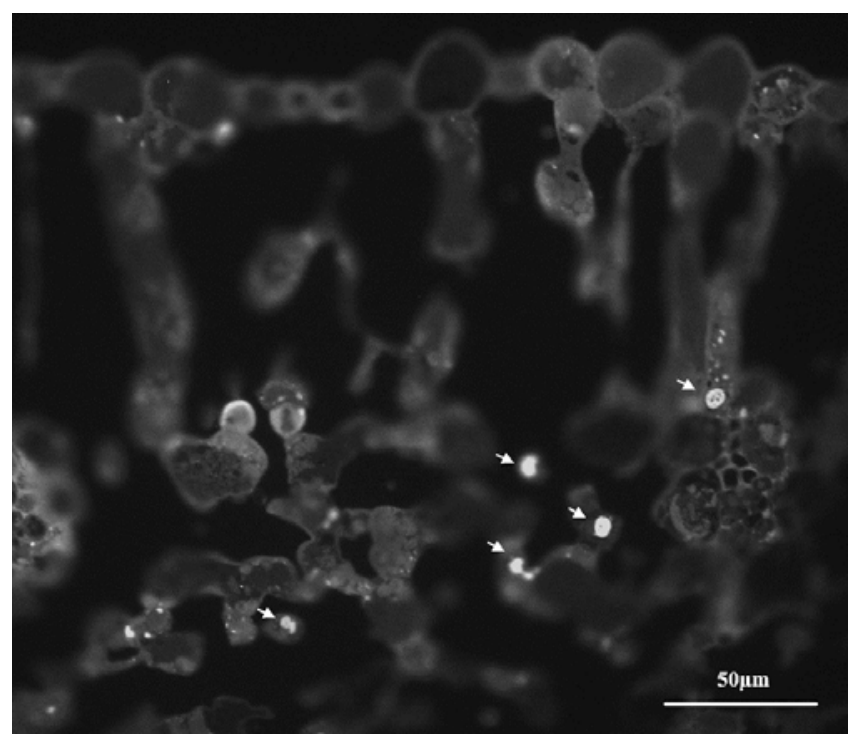

Fig. 3. In situ immunofluorescence detection of the Citrus leprosis virus $C$ (CiLV-C) p29 protein, using antiserum against in-vitro-expressed p29 in a cross section of the leaf lesion of common bean 'IAC Una', caused by mite inoculation of CiLV-C. Arrowheads point to fluorescing roundish structures, interpreted as cytoplasmic viroplasm

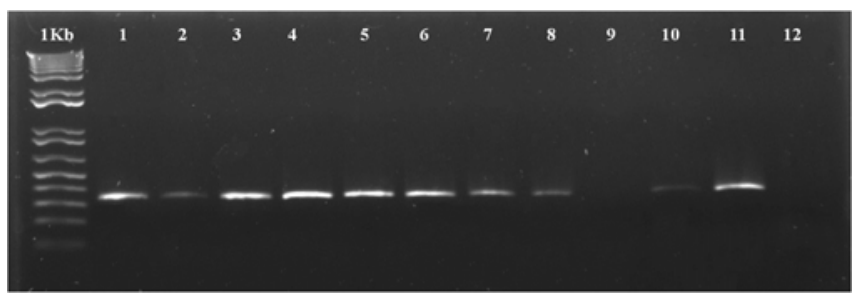

Fig. 4. Electrophoretic profile of $1 \%$ agarose of reverse-transcription polymerase chain reaction products of extracts from local lesions on common bean varieties and lines, infected experimentally with viruliferous Brevipalpus mites. Amplification was made using primers that specifically detect part of the Citrus leprosis virus $C$ movement protein gene (29). Lane $1 \mathrm{~Kb}, 1-\mathrm{kb}$ Ladder (Invitrogen); lane 1, 'BRS Cometa'; lane 2, 'SCS 202 Guará'; lane 3, 'ESAL-767'; lane 4, 'IAC Ybaté'; lane 5 'BRS Esplendor'; lane 6, 'G-3353'; lane 7, 'Mexico 324'; lane 8, 'Baetão 83'; lane 9 , control, uninfected 'Baetão 83'; lane 10, 'IAC Una'; lane 11, IAC Una; lane 12, control, uninfected IAC Una. 
70 by 110 to $120 \mathrm{~nm}$ ), membrane-bounded particles contained in cisternae of the endoplasmic reticulum, is commonly associated with the presence of a large electron-dense inclusion (viroplasm) in the cytoplasm. The type member of BrTV-C is CiLV-C, belonging to the genus Cilevirus. Its genome is bipartite ( 5 and $9 \mathrm{~kb})$ and of positive-sense single-stranded (ss)RNA. Possibly other BrTV-Cs may belong to the same genus. Parts of the genomes of PFGSV (1) and SvRSV (11) have been sequenced, showing sequence similarities with that of CiLV-C. LigRSV and HGSV (23) have not been molecularly characterized yet but their cytopathology indicates that they are BrTV-C. However, an isolate of HGSV from Hawaii was entirely sequenced and, although somewhat similar to CiLV-C in genomic organization and deduced amino acid sequences, due to its three ssRNA fragments, another genus, Higrevirus, has been proposed (32). (ii) The type member of BrTV-N is Orchid fleck virus (OFV), with rod-like particles (40 by 100 to $110 \mathrm{~nm}$ ), usually without membrane, scattered in the nucleus or cytoplasm. They induce an electron lucent nuclear viroplasm. Kondo et al. (24) obtained the entire sequence of OFV, showing that it is composed of two pieces (6 kb each) of negative-sense, ssRNA, and concluded that the genomic organization is similar to that of rhabdoviruses and proposed a new genus, Dichorhabdovirus, for it. Two other BrTV-Ns, CoRSV (17) and ClCSV (26), have been partially sequenced, exhibiting sequence similarities with OFV, and may belong to the same genus as other, as-yet-uncharacterized BrTVNs.

These BrTV-Ns cause chlorotic local lesions in Chenopodium quinoa Willd. and C. amaranticolor Coste \& Reyn. upon mechanical inoculation. If plants with these lesions are kept at 28 to $30^{\circ} \mathrm{C}$, the infection becomes systemic $(3,20,25)$. In these cases, apparently the high temperature disrupts the mechanism that keeps the viruses localized in the lesions. To verify if such an event may occur with CiLV-C, potted plants and detached leaves were placed in a growth chamber at $28^{\circ} \mathrm{C}$. Although no systemic infection occurred, a significant shortening in the period of the appearance of lesions was noticed. Instead of the regular 5 to 6 days, the lesions appeared on the leaves infested with viruliferous mites in 2 days. This may be useful for assays in which a very short infection period is required. It should be mentioned that, because of the fast collapse of the common bean leaf parenchymal cells following infection by mite-inoculated CiLV-C, ELISA or RT-PCR may not always yield positive results, because little viral material is left available for detection. It is advisable to test the samples as soon as lesions become visible.

The susceptibility of common bean to some other BrTV-Cs, though with a limited sampling, opens the possibility to use this plant species to detect them and assay the virus-vector-host relationship. For the tested BrTV-Ns, however, common bean seems unsusceptible following inoculation.

In conclusion, common bean is a reliable tool as an indicator plant in studies of the mite transmission in the CiLV-C pathosystem, serving for a quick, reliable, and inexpensive preliminary diagnosis as well as for several assays to establish the virusvector-host relationship.

\section{Acknowledgments}

This work is part of the M.S. thesis of L. C. Garita in the graduate program on Phytopathology (ESALQ/USP) with a scholarship from Universidade de Costa Rica. It was supported by Fapesp (2008/52691-9) and CNPq (47.1705/2009-8). A. D. Tassi was the recipient of a scientific initiation scholarship of Fapesp (2008/57477-5) and R. F. Calegario of a postdoctoral fellowship of Fapesp (2009/53535-3). Seed from transgenic bean were a kind gift from F. J. L. Aragão (Embrapa Recursos Genéticos e Biotecnologia) and the plants were destroyed after the experiment. We thank C. Omoto, M. A. Nunes, and D. J. de Andrade for providing colonies of Brevipalpus phoenicis.

\section{Literature Cited}

1. Antonioli-Luizon, R. 2009. Sequenciamento parcial do vírus da pinta verde do maracujazeiro (Passion fruit green spot virus-PFGSV), desenvolvimento de métodos para sua detecção e estudos sobre sua variabilidade genética. M.S. thesis, PG Microbiologia Agrícola, ESALQ/USP, Piracicaba, SP, Brazil.
2. Bastianel, M., Novelli, V. M., Kitajima, E. W., Kubo, K. S., Bassanezi, R B., Machado, M. A., and Freitas-Astúa, J. 2010. Citrus leprosis: centennial of an unusual mite virus pathosystem. Plant Dis. 94:284-292.

3. Boari, A. J., Freitas-Astúa, J., Ferreira, P. T. O., Neder, D. G., Nogueira, N. L., Rossi, M. L., and Kitajima, E. W. 2004. Purification and serology of the Coffee ringspot virus. Summa Phytopathol. 30:453-458.

4. Bonfim, K., Faria, J. C., Nogueira, E. O. P. L., Mendes, E. A., and Aragão, F. J. L. 2007. RNAi-mediated resistance to Bean golden mosaic virus in genetically engineered common bean (Phaseolus vulgaris). Mol. Plant-Microbe Interact. 20:717-726.

5. Calegario, R. F., Locali, E. C., Stach-Machado, D. R., Peroni, L. A., Caserta, R., Salaroli, R. B., Freitas-Astúa, J., Machado, M. A., and Kitajima, E. W. 2013. Polyclonal antibodies to the putative coat protein of Citrus leprosis virus $C$ expressed in Escherichia coli: production and use in immunodiagnosis. Trop. Plant Pathol. 38:188-197.

6. Chagas, C. M., Kitajma, E. W., and Rodrigues, J. C. V. 2003. Coffee ringspot virus vectored by Brevipalpus phoenicis (Acari: Tenuipalpidae) in coffee. Exp. Appl. Acarol. 30:203-213.

7. Chiavegatto, L. G. 1995. Transmissão da leprose pelo ácaro Brevipalpus phoenicis (Geijskes, 1939) (Acari: Tenuipalpidae) em citros. Pages 49-56 in: Leprose dos Citros. C. A. L. Oliveira and L. C. Donadio, eds. Fundação de Estudos e Pesquisas em Agronomia, Medicina Veterinária e Zootcnia, Jaboticabal, SP, Brazil.

8. Childers, C. C., Rodrigues, J. C. V., Derrick, K. S., Achor, D. S., French, J. V., Welbourn, W. C., Ochoa, R., and Kitajima, E. W. 2003. Citrus leprosis and its status in Florida and Texas: past and present. Exp. Appl. Acarol. 30:181-202.

9. Colariccio, A., Lovisolo, O., Chagas, C. M., Galletti, S. R., Rossetti, V., and Kitajima, E. W. 1995. Mechanical transmission and ultrastructural aspects of citrus leprosis disease. Fitopatol. Bras. 20:208-213.

10. Fawcett, H. S. 1911. Scaly bark or nail head rust of citrus. Fla. Agric. Exp. Stn. Bull. 106.

11. Ferreira, P. T. O., Locali-Fabris, E. C., Freitas-Astúa, J., Antonioli-Luizoni, R., Gomes, R. T., Machado, M. A., and Kitajima, E. W. 2007. Caracterização de um vírus baciliforme isolado de Solanum violaefolium transmitido pelos ácaros Brevipalpus phoenicis e Brevipalpus obovatus (Acari: Tenuipalpidae). Summa Phytopathol. 33:264-269.

12. Frezzi, M. S. 1940. La lepra explosiva del naranjo-investigaciones realizadas por el laboratorio de patología de Bella Vista (Corrientes). Bol. Frutas y Hortalizas. Buenos Aires. Min. Agric. Nación (Buenos Aires) 5.

13. Garita, L. C., Tassi, A. D., Calegario, R. F., and Kitajima, E. W. 2012. Amplia-se a lista de hospedeiras experimentais do virus da leprose C (Citrus leprosis virus-CiLV-C). Summa Phytopathol. 38 (Suppl.) Resumo 25. CD Rom.

14. Groot, T. V. M. 2006. The effects of symbiont induced haploid thelytoky on the evolution of the Brevipalpus mites. Ph.D. diss. University of Amsterdam.

15. Groot, T. V. M., Freitas-Astúa, J., and Kitajima, E. W. 2006. Brevipalpus phoenicis transmits citrus leprosis virus, cytoplasmic type (CiLV-C) to common bean (Phaseolus vulgaris) under experimental conditions. Virus Rev. Res. $11: 67-68$.

16. Kikkert, M., van Poelwijk, F., Storms, M., Kassies, W., Bloksma, H., van Lent, J., Kormelink, R., and Goldbach, R. 1997. A protoplast system for studying tomato spotted wilt virus infection. J. Gen. Virol. 78:1755-1763.

17. Kitajima, E. W., Chagas, C. M., Braghini, M. T., Fauzuoli, L. C., LocaliFabris, E. C., and Salaroli, R. B. 2011. Natural infection of several Coffea species and hybrids and Psilanthus ebracteolatus by the Coffee ringspot virus (CoRSV). Sci. Agric. 58:503-507.

18. Kitajima, E. W., Chagas, C. M., Harakava, R., Calegario, R. F., FreitasAstúa, J., Rodrigues, J. C. V., and Childers, C. C. 2011. Citrus leprosis in Florida, USA, appears to have been caused by the nuclear type of Citrus leprosis virus (CiLV-N). Virus Rev. Res. Online publication. http://www. virusreviewsandresearch.com/ISSUE16_1-2.html

19. Kitajima, E. W., Chagas, C. M., and Rodrigues, J. C. V. 2003. Brevipalpustransmitted plant virus and virus-like diseases: Cytopathology and some recent cases. Exp. Appl. Acarol. 30:135-160.

20. Kitajima, E. W., Kubo, K. S., Ferreira, P. T. O., Alcântara, B. K., Boari, A. J., Gomes, R. T., Freitas-Astúa, J., Rezende, J. A. M., Moraes, G. J., and Salaroli, R. B. 2008. Chlorotic spots on Clerodendrum, a disease caused by a nuclear type of Brevipalpus (Acari: Tenuipalpidae) transmitted virus. Sci. Agric. 65:36-49.

21. Kitajima, E. W., and Nome, C. F. 1999. Microscopia eletrónica en virologia vegetal. Pages 59-87 in: Métodos para detectar patógenos sistémicos. D Docampo and S. L. Lenardon, eds. Instituto de Fitopatologia y Fisiologia and Japan International Cooperation Agency, Córdoba, Argentina.

22. Kitajima, E. W., Rezende, J. A. M., Rodrigues, J. C. V., Chiavegatto, L. G., Piza, C. T., Jr., and Morozini, W. 1997. Green spot of passion fruit, a possible viral disease associated with infestation by the mite Brevipalpus phoe nicis. Fitopatol. Bras. 22:555-559.

23. Kitajima, E. W., Rodrigues, J. C. V., and Freitas-Astúa, J. 2010. An annotated list of ornamentals naturally found infected by Brevipalpus mite-transmitted viruses. Sci. Agric. 67:348-371.

24. Kondo, H., Maeda, T., Shirako, Y., and Tamada, T. 2006. Orchid fleck virus is a rhabdovirus with an unusual bipartite genome. J. Gen. Virol. 87:2413-2421.

25. Kondo, H., Maeda, T., and Tamada, T. 2003. Orchid fleck virus: Brevipal- 
pus californicus mite transmission, biological properties and genome structure. Exp. Appl. Acarol. 30:215-223.

26. Kubo, K. S., Antonioli-Luizon, R., Freitas-Astúa, J., and Kitajima, E. W. 2007. Diagnose molecular do vírus da mancha clorótica de Clerodendron (ClCSV). Summa Phytopathol. 32 :S12.

27. Lenardon, S. L. 1999. Serologia. Pages 11-39 in: Métodos para detectar patógenos sistémicos. D. Docampo and S. L. Lenardon, eds. Instituto de Fitopatologia y Fisiologia and Japan International Cooperation Agency, Córdoba, Argentina.

28. León, G. A., Becerra, C. H., Freitas-Astúa, J., Salaroli, R. B., and Kitajima, E. W. 2008. Natural infection of Swinglea glutinosa by the Citrus leprosis virus, cytoplasmic type (CiLV-C) in Colombia. Plant Dis. 92:1364.

29. Locali, E. C., Freitas-Astúa, J., Souza, A. A., Takita, M. A., Astúa-Monge, G., Antonioli, R., Kitajima, E. W., and Machado, M. A. 2003. Development of a molecular tool for the diagnosis of leprosis, a major threat to citrus production in the Americas. Plant Dis. 87:1317-1321.

30. Locali-Fabris, E. C., Freitas-Astúa, J., and Machado, M. A. 2012. Genus Cilevirus. Pages 1139-1142 in: Virus Taxonomy: Classification and Nomenclature of Viruses: Ninth Rep. Int. Committee on Taxonomy of Viruses. A. M. Q. King, M. J. Adams, E. B. Carstens, and E. J. Lefkowitz, eds. Elsevier, San Diego, CA.

31. Locali-Fabris, E., Freitas-Astúa, J., Souza, A. A., Takita, M. A., AstúaMonge, G., Antonioli-Luizon, R., Rodrigues, V., Targon, M. L. P. N., and Machado, M. A. 2006. Complete nucleotide sequence, genomic organization and phylogenetic analysis of Citrus leprosis virus cytoplasmic type. J.
Gen. Virol. 87:2721-2729.

32. Melzer, M. J., Sether, D. M., Borth, W. B., and Hu, J. S. 2012. Characterization of a virus infecting Citrus volkameriana with citrus leprosis-like symptoms. Phytopathology 102:122-127.

33. Musumeci, M. R., and Rossetti, V. 1963. Transmissão de sintomas de leprose dos citros pelo ácaro Brevipalpus phoenicis. Ciên. Cult. 15:228.

34. Nunes, M. A., Bergamini, M. P., Coerini, L. F., Bastianel, M., Novelli, V. M., Kitajima, E. W., and Freitas-Astúa, J. 2012. Citrus leprosis virus C naturally infecting Commelina benghalensis, a prevalent monocot weed of citrus orchards in Brazil. Plant Dis. 96:770.

35. Nunes, M. A., Oliveira, C. A. L., Oliveira, M. L., Kitajima, E. W., Hilf, M. E., Gottwald, R. T., and Freitas-Astúa, J. 2012. Transmission of Citrus leprosis virus, cytoplasmic type, by Brevipalpus phoenicis (Geijskes) to alternate host plants found in citrus orchards. Plant Dis. 96:968-972.

36. Pascon, R. C, Kitajima, J. P., Breton, M. C., Assumpção, L., Greggio, C., Zanca, A. S., Okura, V. K., Alegria, M. C., Camargo, M. E., Silva, G. G. C., Cardozo, J. C., Vallin, M. A., Franco, S. F., Silva, V. H., Jordão, H., Jr. Oliveira, F., Giachetto, P. F., Ferrari, F., Aguilar-Vildoso, C. I., Franchiscini, F. J. B., Silva, J. M. F., Arruda, P., Ferro, J. A., Reinach, F., and Silva, A. C. R. 2006. The complete nucleotide sequence and genomic organization of Citrus leprosis associated virus, cytoplasmic type (CiLV-C). Virus Gene 32:289-298.

37. Rodrigues, J. C. V., Kitajima, E. W., Childers, C. C., and Chagas, C. M. 2003. Citrus leprosis virus vectored by Brevipalpus phoenicis (Acari: Tenuipalpidae) on citrus in Brazil. Exp. Appl. Acarol. 30:161-179. 